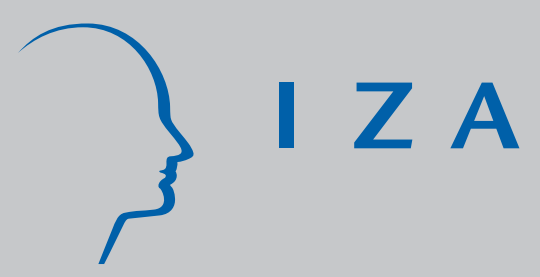

IZADP No. 2578

The Vanishing Bequest Tax:

The Comparative Evolution of Bequest Taxation in Historical Perspective

Graziella Bertocchi

J anuary 2007 


\title{
The Vanishing Bequest Tax: The Comparative Evolution of Bequest Taxation in Historical Perspective
}

\author{
Graziella Bertocchi \\ Università di Modena e Reggio Emilia, \\ CEPR, CHILD and IZA
}

Discussion Paper No. 2578

January 2007

IZA
P.O. Box 7240
53072 Bonn
Germany

Phone: +49-228-3894-0

Fax: +49-228-3894-180

E-mail: iza@iza.org

\begin{abstract}
Any opinions expressed here are those of the author(s) and not those of the institute. Research disseminated by IZA may include views on policy, but the institute itself takes no institutional policy positions.
\end{abstract}

The Institute for the Study of Labor (IZA) in Bonn is a local and virtual international research center and a place of communication between science, politics and business. IZA is an independent nonprofit company supported by Deutsche Post World Net. The center is associated with the University of Bonn and offers a stimulating research environment through its research networks, research support, and visitors and doctoral programs. IZA engages in (i) original and internationally competitive research in all fields of labor economics, (ii) development of policy concepts, and (iii) dissemination of research results and concepts to the interested public.

IZA Discussion Papers often represent preliminary work and are circulated to encourage discussion. Citation of such a paper should account for its provisional character. A revised version may be available directly from the author. 


\section{ABSTRACT}

\section{The Vanishing Bequest Tax: The Comparative Evolution of Bequest Taxation in Historical Perspective}

Several countries have recently abolished or significantly reduced their taxes on bequests. Bequest taxes, on the other hand, were among the first to be introduced when modern systems of taxation were developed at the end of the nineteenth century. We propose an explanation for these facts which is based on a dynamic political economy model where redistribution is determined not only by wealth inequality but also by sectoral reallocation from agriculture to manufacturing. The model shows that the dynamics of capital accumulation induce a reduction of wealth inequality, which is further accelerated by the redistributive impact of the bequest tax. Through a standard politico-economic mechanism, wealth equalization pushes toward a reduced role of the bequest tax. At the same time, however, a second mechanism is at work, with structural reallocation from agriculture to manufacturing shifting the tax base from hard-to-avoid taxes on land toward easy-to-avoid taxes on capital. The differential treatment of land and capital introduces a source of asymmetry in the tax system which interferes with the determination of the dynamic political equilibrium of the model. Its effect is to compress bequest taxation but also to delay its gradual reduction due to declining wealth inequality. A number of extensions to the basic model allow to match our theory with the long-term evolution of bequest taxation in modern democracies and with the drastic discrepancies currently observed between tax systems in developed and underdeveloped countries.

JEL Classification: H20, P16, N40, O40

Keywords: bequest tax, inequality, structural reallocation, redistribution, voting

Corresponding author:

Graziella Bertocchi

Dipartimento di Economia Politica

Università di Modena e Reggio Emilia

Viale Berengario 51

I-41100 Modena

Italy

E-mail: bertocchi.graziella@unimore.it

\footnotetext{
* I would like to thank A. Auerbach, G. Bellettini, M. Cervellati, V. Galasso, T. Piketty, F. Portier, E. Proto, G. Saint-Paul, E. Sheshinski, G. Tabellini, and workshop participants at Toulouse, BOMOPA, CESifo, Warwick, CEPR Public Policy Symposium, and IGIER, for comments and suggestions.
} 


\section{Introduction}

In June 2006, a clear majority of the US Senate voted a bill for permanent repeal of the tax on inherited wealth, but the measure fell short of the 60 votes required to secure passage. The US estate tax had been phased out over ten years under the tax-reduction package adopted in 2001 . The legislation provided for gradual phase-out by 2010, followed by its complete restoration in 2011, but the then common perception was that the Bush administration would have tried to eliminate the paradoxical 2011 restoration in subsequent years and make the tax cut permanent. Action in that direction was indeed undertaken in April 2005 when the House of Representatives passed permanent repeal of the estate tax. However, the Senate postponed scheduled action in September 2005 after hurricane Katrina. The recent vote in the Senate reignited debate about the future of bequest taxation. Whether or not full repeal will be achieved by the current administration, it is certain that a drastic cut of the tax burden will be ensured even after 2010. This will represent the final stage of a reduction process initiated in the 1930s for a tax that had been adopted during the Progressive Era mainly as a means to avoid excessive wealth concentration.

The US are not alone in following this pattern of reduced fiscal pressure on inherited wealth, since several other countries of the world have recently abolished or significantly reduced their taxes on bequests. Canada, Australia, New Zealand, and Italy are among those that have abolished their bequest tax. For many others, the importance of the tax both in terms of GDP and total revenues is now at a historical low point.

No explanation has yet been offered for the vanishing role of bequest taxation. It is indeed puzzling that this happens at a time when the fact that wealth is more concentrated than income has become a well-established stylized fact which. ${ }^{1}$ Together with persuasive additional evidence that intergenerational transmission is a crucial factor in explaining wealth inequality, ${ }^{2}$ this would call for an important role of bequest taxation, a policy tool that has always been employed to enhance progressivity within a tax system. ${ }^{3}$ However, another body of recent empirical evidence has shown that wealth inequality has declined dramatically during the 20th century. ${ }^{4}$ This suggests a rationale for the evolution of bequest taxation which we develop within a politico-economic model

\footnotetext{
${ }^{1}$ See for example Diaz-Gimenez et al.(1997) for data on the US in the postwar period.

${ }^{2}$ See Harbury (1973) and Kotlikoff and Summers (1981), among others.

${ }^{3}$ Piketty and Saez (2007) present evidence on relevance of estate taxes for progressivity in historical and international perspective.

${ }^{4}$ See Wolff (1996), Atkinson and Piketty (2007), and the discussion in Section 3.
} 
of a dynamic economy where the distribution of wealth varies over time according to the stylized facts.

The first channel at work in our model links inequality, voting and redistribution in the tradition of Meltzer and Richard's (1981) application of the median voter theorem. However, Meltzer and Richard (1981) focus on a static setting with a time invariant wealth distribution, where the expansion on the size of government is explained by an exogenous extension of the voting franchise. Here we apply the median voter theorem to a dynamic model where non-overlapping generations of agents, differentiated only in terms of their initial wealth holdings, derive utility from their own consumption and from bequests. In other words, all saving is bequeathed. Since there is no uncertainty, all bequests are voluntary. A tax is imposed on bequests in order to finance a redistributive scheme. To concentrate on the redistributive effect of the tax, we assume preferences that guarantee the absence of distortions to the saving/bequest decision. In this framework, the voter with median bequest will choose in each period the tax rate. The analysis of the model shows that wealth inequality declines over time. This process is driven by the accumulation of bequests and is also reinforced by redistributive taxation. As inequality declines, the median voter's relative holdings of bequests get closer and closer to the mean, inducing a sequence of decreasing tax rates. Moreover, in our dynamic framework, the effect of inequality reduction is magnified by the process of capital accumulation, which further accelerates the decline of the tax. These preliminary results replicate the observed secular decline of wealth inequality and represent a first step toward the understanding of the declining importance of bequest taxes.

However, while we believe that the evolution of inequality represents a fundamental force affecting bequest taxation, cross-country and time-series differences in inequality cannot fully explain the observed stylized facts. In other words, the standard Meltzer and Richard (1981) political economy mechanism cannot capture the complexity of the workings of the bequest tax system. Therefore, we add a second channel by embedding the same mechanism within a richer two-sector model where bequests consist of two components, land and capital, whose relative weight varies over time with industrialization. Land and capital are subject to an asymmetry when subject to taxation, with taxes on capital being easier to avoid than taxes on land. Indeed taxes on landed property are much more difficult to elude or evade than those on capital or financial wealth in general, since it cannot be hidden or moved to a tax haven. We take this asymmetry as a deeply-rooted, invariant characteristic of a tax system, which could only be affected by radical transformation but not by routine fiscal policy. Under the expanded framework, we can evaluate the impact of structural 
reallocation from agriculture to manufacturing on the tax bases of countries at varying stages of development, uncovering the fact that industrialization shifts a country's wealth, and thus its bequest tax base, from hard-to-avoid taxes on land toward easy-to-avoid taxes on capital. Industrialization thus erodes the tax base in an asymmetric fashion. The asymmetry between land and capital with respect to tax avoidance interferes with the process of structural reallocation and more generally with the determination of the dynamic political equilibrium of the model. Our results show that, for given inequality, the level of the bequest tax decreases in the degree of avoidance of capital taxation. Intuitively, the median voter sets a lower tax, the higher is the tax asymmetry in favor of capital relative to land. On the other hand, this asymmetry delays the reduction of the tax due to wealth equalization, because the tax base is disproportionately represented by that component of the bequest, land, which is not subject to equalization. Thus a higher avoidance parameter makes the tax lower but also makes tax reduction more sluggish. Our results can explain why in the US, a country with high tax compliance (i.e., low avoidance), revenues from bequest taxes have been high relatively to the rest of the OECD countries, but are now being phased out, while in the EU bequest taxes have been lower, but their role is not being debated. ${ }^{5}$ Moreover, different degrees of avoidance could be the explanation of the radical differences between the systems of taxation in developed and underdeveloped countries, with wealth and bequest taxes playing a minor role in the latter.

An important extension of the model allows for franchise requirements to be imposed on the voting mechanism. The goal of this extension is three-fold. First, it broadens the horizon covered by the model backward, to explain why bequest taxes were among the first to be introduced when modern systems of taxation were developed during the nineteenth century. If, in an early stage, voting is restricted, even if wealth is unequally distributed no bequest tax is imposed in a political equilibrium. Subsequently, with the gradual extension of the franchise, a tax on bequests is introduced and expanded. It is only after full democratization is achieved that the process of wealth equalization starts exerting on the tax the impact previously described in the basic version of the model. Therefore, the introduction of a franchise requirement allows to reproduce the humpedshaped long term evolution of the tax starting from the 19th century for those countries that are now modern industrial democracies. Second, in the spirit of Sokoloff and Zolt (2005) who analyze

\footnotetext{
${ }^{5}$ Italy is an exception: the bequest tax has been abolished in 2001 by the center-right government then in power, but the newly elected center-left coalition has already reintroduced it.
} 
the comparative evolution of tax systems in the Americas over the 19th and 20th centuries, we want to offer an explanation for why different countries historically established different tax structures, with Latin America developing a highly regressive system despite large inequality, and more equal North America embracing instead a progressive system. A franchise restriction can capture the idea that in those societies that began with extreme inequality, elites were able to establish a legal framework that guaranteed them a monopoly over political power, and thus to design a tax system that preserved inequality. In other words, the model shows that, under extreme poverty, democratization may never start and bequest taxes may never implemented. This conclusion can also be applied to today's underdeveloped countries, where a low degree of democracy, captured again by restrictions to political power and in turn linked to extreme inequality, can explain the minor role played by wealth and bequest taxes.

Another extension of the model accounts for the observed expansion of the size of government in the face of reduced revenues from bequests, by introducing wage taxation and by exploiting the impact of industrialization on the wage tax base. Finally, we discuss how the model could be adapted to capture the impact of the residential capital stock on bequest taxation.

The paper is organized as follows. Section 2 introduces the related literature. Section 3 reviews the historical evidence on bequest taxation, as well as wealth inequality, structural change, and franchise extension. Section 4 presents the basic model. Section 5 contains the analysis of the model. Section 6 explores extensions of the basic model. Section 7 summarizes our findings, derives their implications for policy, and indicate directions for related future research.

\section{Related literature}

This paper is first of all related to the stream of the literature, initiated by Alesina and Rodrik (1994) and Persson and Tabellini (1994), which has applied the basic Meltzer and Richard (1981) framework to dynamic growth models. However, due to the non-neoclassical properties of the production function, in these models once again wealth distribution remains time invariant, so that the median voter choice is also time invariant. A separate stream of the literature has instead focused explicitly on the evolution of wealth distribution, with Galor and Zeira (1993) showing that under liquidity constraints the evolution of wealth distribution can lead to persistent, steady-state inequality. In their setup, however, no attention is paid to voting mechanisms, and therefore on the implications of the evolution of inequality on the political equilibrium and the associated sequence 
of taxes. This paper establishes a link between these two streams by introducing a median voter mechanism into a model where the distribution of wealth evolves with income growth. ${ }^{6}$

Since we focus on a specific policy tool, the bequest tax, as the object of the median voter choice, and we show how it evolves with wealth inequality, this paper is also naturally related with the literature on intergenerational wealth transmission through bequests. Laitner (2001) establishes the relevance of dynastic behavior for the emergence of wealth concentration. De Nardi (2004) shows that only with voluntary, rather than accidental, bequests individual saving behavior can generate a distribution of wealth that is more concentrated than that of labor earnings. Different systems of inheritance also matter for the evolution of inequality, as shown by Bertocchi (2006) who compares primogeniture and equal partition.

There is also a vast research body that has studied optimal bequest taxation in a variety of settings. The accent is usually on the trade-off between the redistributive equity it conveys and the distortions to wealth accumulation it can cause. Most of these investigations are inherently static, or else conducted at steady state. Cremer and Pestieau (2005) provide a survey for this normative contributions, from the standpoint of both equity and efficiency. Blumkin and Sadka (2003) compare the properties of the optimal estate tax under altruistic and accidental bequests, and conclude that estate taxation is supported only under the latter. Kopczuk (2003) links estate taxation to social security. Aura (2004) compares the bequest tax with the capital income tax, extending Chamley (1986) and finding that in the long run the estate tax rate should be set to zero. Fahri and Werning (2006) show that the optimal estate tax is progressive under a welfare criterion that values future generations directly by placing a positive weight on their welfare. Benhabib and Bisin (2006) study the dynamics of the distribution of wealth in an overlapping generations economy with bequests and find that social welfare is maximized with zero estate taxes. With respect to this literature, we focus attention on redistribution under voluntary bequests and abstract from consideration of other forms of saving behavior and of distortions to the saving/bequest decision. ${ }^{7}$

\footnotetext{
${ }^{6}$ While a full characterization of a dynamic median voter setup is beyond the scope of the present paper, since as in Saint Paul and Verdier (1993) we adopt the simplifying assumption of a non-overlapping generations model with a 'joy of giving' bequest motive, this work is also related to more general treatments of capital taxation such as Krusell and Rios-Rull (1999), who calibrate a fully dynamic model to match postwar US data, Azzimonti et al. (2005), who provide an analytical characterization of time-consistent Markov-perfect equilibria under repeated voting, and Hassler et al. (2003), who perform a similar task under non-neoclassical assumptions. Other examples of voting models where wealth distribution varies are Benabou (2000) and Das and Ghate (2004).

${ }^{7}$ Another stream of the public economics literature has focused on the post-war evolution of corporate taxation, prompted by the fact that in the US corporate tax revenues fell precipitously during the late 1960s and the1970s.
} 
Land and the sectoral distribution of output play a crucial role in our model. Among others, Cukierman et al. (1992) and Aizenman and Jinjarak (2006) have applied the distinction between easy- vs. hard-to-avoid taxes, that we apply to capital vs. land, to other specific forms of government revenue, namely income taxes vs. seigniorage. Other related implications of the role of land in development are discussed in Eaton (1987), who develops a dynamic specific-factors model similar to ours, Gollin et al. (2002), who stress the role of agriculture in explaining cross-country income disparities, and Galor et al. (2006), who explore the impact of land ownership structure on growth. Finally, Caucutt et al. (2006) and Bertocchi (2006) study the implications of an economy's structural transformation for the emergence of social security and for the transition from primogeniture to partition, respectively.

Finally, this work is also deeply connected with the research program which has focussed on the connection between development and institutions in a long-term perspective, in the tradition of North (1981). More recently, this literature has been enriched by contributions of Engerman and Sokoloff (1997) and Acemoglu and Robinson (2000). The joint evolution of the economic and political system is modeled, among others, by Cervellati et al. (2005), who show how economic inequality is the main determinant of economic and political institutions. Sokoloff and Zolt (2005), on the basis of evidence collected for the Americas, argue that tax systems are among the oldest and most fundamental of institutions, and suggest that inequality is the main force driving the evolution of their structure.

\section{Evidence}

\subsection{Estate taxation}

All modern industrial economies rely extensively on progressive personal income taxes. None derives significant revenues from taxes on wealth transfers such as inheritance or estate taxes. Namely, the first is levied on the share of the bequest received by the individual recipient, and is applied in most European countries. The latter is levied on the total estate of the donor, regardless of the characteristics and the number of recipients, and is applied for instance in the US and the UK.

Gale and Slemrod (2001) provide a history of the estate tax in the US, where is was first introduced in 1797 , only to be eliminated in 1802. Subsequent attempts to tax bequests were in However, since the early 1980s this trend has been reversed (see Auerbach, 2006), suggesting that corporate and estate taxation may not be responding to the same factors. 
place between 1862 and 1870, in 1894, and between 1898 and 1902, typically in association with military expenses. The precursor of the modern estate tax was finally introduced in 1913, as an attempt to make the tax system more progressive. Legislation was hardly altered until 1976, when the Tax Reform Act significantly reduced rates and raised exemptions. The pattern was confirmed in subsequent reforms, with a marked revenue reduction. As mentioned in the introduction, in 2001 the US Congress passed a bill according to which estate taxes are scheduled for repeal in 2010, even if they are currently supposed to be re-enacted in 2011.

Among OECD countries, the peak of the importance of bequest taxation over total revenues was reached between the 1930s and the 1940s. While most countries still have some form of bequest taxation, Canada abolished its tax in 1972, Australia in 1977, New Zealand in 1992, and Italy in 2001 (Duff, 2005).

Cremer and Pestieau (2001) report OECD statistics on wealth transfer taxes for a sample of industrialized countries in 1998. As a share of GDP, these taxes play an especially important role in France $(0.51 \%)$ and are significant also in the US $(0.36 \%)$, while they are negligible for Italy $(0.08 \%)$, with the other European countries somewhere in between. As a share of total revenues, the US lead with $1.16 \%$, and again Italy lags with $0.13 \%$. However, comparisons are complicated by the fact that, for instance, the deductible is much higher in the US, so that estate taxation in the US concerns only the very wealthy. Since 1965, the evolution of bequest taxes has not been uniform, with a more marked decline in the US and the UK at the beginning of the period, and stability in most other cases.

A commonly cited possible reason for the low revenues generally associated with bequest taxes is the administrative costs associated with them, which tend to be higher for inheritance taxes (Aaron and Munnell, 1992). Avoidance, both in the form of elusion and evasion, is estimated to be particularly widespread for bequest taxes (Duff, 2005). Discretionary trusts, for example, could be used to transfer wealth while avoiding the tax. Gifts, to some extent, can also be used as a means to reduce its impact. More affluent taxpayers tend to be able to employ more sophisticated tax-avoidance strategies. Moreover, different components of wealth are subject to different degrees of tax avoidance, with tangible assets such as land and real estate being much harder to hide or transfer abroad than financial assets. While specific compliance data on bequest taxation are not available, it is useful to report that the overall rate of tax compliance is estimated at $74.5 \%$ for the US and at $29.5 \%$ for Italy, with even lower figures for underdeveloped countries (the source is the World Economic Forum, 1996). 
Sokoloff and Zolt (2005) document the evolution of tax systems in the Americas from the 19th century, and show how wealth and bequest taxes were less significant in Latin America as opposed to North America.

The radical differences between the current systems of taxation between developed and underdeveloped countries, with wealth and bequest taxes playing a minor role in the latter, are documented by Burgess and Stern (1993).

\subsection{Wealth inequality and structural change}

To understand the determinants of bequest tax revenues in the past century, we also collect information on the underlying economic fundamentals and in particular on the evolution of wealth inequality and the process of structural transformation from agriculture to manufacturing.

Recent empirical evidence has shown that wealth inequality has declined dramatically during the 20th century. Wolff (1996) finds a reduction in wealth inequality in the US, UK and Sweden over the past 80 years, confirming previous findings by Atkinson et al. (1989) on the fall in the share of top wealth-holders in the UK. Further long-term evidence on the basis of tax records is collected by Atkinson and Piketty (2007) for a selection of OECD countries. Despite this common trend, countries still differ considerable regarding their degrees of wealth inequality. Kapteyn and Panis (2002) show that in 1998 the ratio between median and mean net wealth was 41.4 in the US and 57.2 in Italy.

The same period also witnesses an acceleration of the structural transformation of the most advanced countries from agricultural to industrial economies, with a parallel shift from land to capital as the main component of national wealth. Industrialization and capital accumulation can be tracked by the proportion of the labor force in agriculture, which drops continuously throughout the century for all countries, despite marked differences both in the initial conditions and in the speed of the process. In the US, for instance, the agricultural share drops from $37.6 \%$ in 1900 to $3.3 \%$ in 1980 , while in Italy it drops from $61.8 \%$ to $14.6 \%$ over the same period (the source is Banks, 2001). Cross-country direct evidence on wealth composition is presented for the year 2000 by Davies et al. (2006), who show that real assets, particularly land and farm assets, are more important in less developed countries. Historical data are scarce, but Frankema (2006) provides estimates for the pre-war Gini coefficients of land holdings for a sample of countries and shows that, in the 1930s, they were higher in Western Europe than in the US (with Italy at 71.5, Germany at 70.5, the UK at 62.6 , and the US at 60.1). Moreover, land inequality appears to be relatively stable 
over the 20th century, despite the influence of some post-war agrarian reforms. By the 1980s, it is actually larger in many countries (with Italy at 73.3 , the UK at 64.4 , and the US at 71.9 ).

\subsection{Franchise extension}

In this section, we briefly discuss the historical evidence related to the extension of the franchise, with the goal of comparing the timing of this process with that of the economic transformations just described.

Following Bendix (1978) and Flora (1983), again we will refer to a few case studies, starting with the United Kingdom, where suffrage was gradually extended over the course if the 19th and early 20th century. The 1832 Reform Act granted voting rights to the top $3.5 \%$ of population, while the 1867 Second Reform Act extended them to the $7.7 \%$, followed by further extensions. It is only in 1918 that universal male (over age 21) and female (over 30) suffrage was introduced with the Representation of the People Act, which lifted all property restrictions at least for men.

The history of suffrage in the United States is written through constitutional amendments, starting with the 1870 15th Amendment, which barred state laws from restricting any race from voting, until the 1964 24th Amendment, which stated that neither Congress nor the states may condition the right to vote in federal elections on payment of a poll tax or other type of tax.

In Italy a first extension of the property-based electoral law was introduced in 1882, while universal male suffrage was only reached in 1912 for 30 years old people, and in 1918 for 21 years old (even though women were allowed to vote only in 1946).

Most of the other Western European countries, as well as Canada, Australia and New Zealand, reached universal men suffrage by 1920. To conclude, the years immediately following World War I witness the completion of a widespread democratization process initiated during the previous century.

\section{The model}

\subsection{Production}

The economy displays two specific-factor technologies, producing an agricultural good and a manufacturing good using three factors: land, capital, and labor. Land is in fixed supply, and equal to $L$. At time $t$, production of the agricultural good, $Y_{t}^{A}$, uses labor $N_{t}^{A}$ and land $L$, according to 


$$
Y_{t}^{A}=L^{\alpha} N_{t}^{A 1-\alpha}
$$

where $0<\alpha<1$. Production of the manufacturing good, $Y_{t}^{M}$, uses labor $N_{t}^{M}$ and capital $K_{t}$ according to

$$
Y_{t}^{M}=K_{t}^{\alpha} N_{t}^{M 1-\alpha}
$$

The agricultural good is not storable and can be used only for consumption, while the manufacturing good can either be used for consumption or bequeathed to children, who will in turn employ it as capital in the manufacturing sector. Labor is perfectly mobile between sectors at no cost.

\subsection{Endowments}

We consider a non-overlapping generations model with bequests where individuals live for a single period. There is no population growth, so that each individual gives birth to a single child, to whom he leaves a bequest. All individuals receive a unit of homogeneous labor endowment which is supplied inelastically. Each individual also receives a capital bequest $k_{t}^{i}$. The distribution of initial capital bequests is assumed to be skewed to the right, i.e., the median capital bequest $k_{0}^{m}$ is smaller than the mean $k_{0}$. Since ours is not a theory of how wealth inequality is generated, we simply assume it as a fact. The distribution of capital bequests evolves over time but as we will show its property will persist. Finally, each individual also receives a land bequest $e^{i}$, i.e., a fraction of the fixed amount of land $L$. While the evolution of capital bequests will be optimally determined through individual maximization, land is simply passed on from each individual to his only child, ${ }^{8}$ so that the distribution of land is time invariant. ${ }^{9}$ The distribution of land bequests is also assumed to be skewed to the right, i.e., the median capital bequest $e^{m}$ is smaller than the mean $e$. Moreover, we assume that the distributions of land and capital are perfectly correlated and that land is more unequally distributed than capital, with $\frac{e^{m}}{e}<\frac{k_{0}^{m}}{k_{0}}$. The latter assumption is actually not required for the subsequent analysis, and is simply introduced for the sake of realism.

\footnotetext{
${ }^{8} \mathrm{~A}$ market for land could be introduced without modifying the main results, but would not allow a closed form solution. The fact that land has always been less liquid than capital, because of entails and other forms of legal limitations to the alienation of family land, is widely documented by historians (Goody et al., 1976) and justifies our simplifying assumption.

${ }^{9}$ Frankema (2006) confirms the substantial stability of Gini coefficients for land holdings throughout the 20th century.
} 
At each time $t$, total bequests are the sum of land and capital bequests, i.e., $b_{t}^{i}=k_{t}^{i}+e^{i}$, with $\frac{e^{m}}{e}<\frac{b_{t}^{m}}{b_{r}}<\frac{k_{t}^{m}}{k_{t}}$.

Initially, the aggregate size of the capital is small relative to land, so that aggregate initial wealth in the economy is composed mostly of land.

\subsection{Preferences}

Individual preferences are given by

$$
u_{t}^{i}=(1-\partial) \log c_{t}^{i}+\partial \log k_{t+1}^{i}
$$

where $c_{t}^{i}$ is the individual's level of consumption, such that $c_{t}^{i}=c_{t}^{A i}+c_{t}^{M^{i}}$, where $c_{t}^{A i}$ and $c_{t}^{M^{i}}$ are the individual consumption levels of the agricultural and manufacturing goods, respectively. The agricultural and manufacturing goods are assumed to be perfect substitutes in consumption, i.e., their relative prices are fixed and set equal to 1 . The term $k_{t+1}^{i}$ represents the capital bequest for the child, and $\partial$ is a preference parameter, such that $0<\partial<1$. The 'joy of giving' bequest motive that we assume is analytically convenient since it implies that the individual does not perceive any indirect effects of current choices on future decisions. Moreover, under our assumptions on preferences a bequest tax is not going to affect the consumption-bequest decision. Thus our formulation allows to focus on the redistributive impact of taxation without having to worry about distortions and a potential equity-efficiency trade-off.

Individuals maximize their utility subject to the following budget constraint:

$$
c_{t}^{i}+k_{t+1}^{i} \leq I_{t}^{i}
$$

where $I_{t}^{i}$ is individual income.

Production in both sectors takes place in each period by combining labor, land and capital according to equations (1) and (2), so that each individual receives a wage income from his labor endowment, an interest income from his capital bequest, and a rental income from his land bequest. The level of the wage earned in agriculture and manufacturing is identical since labor is perfectly mobile. Moreover, wage income is identical for all individuals since labor endowments are homogeneous, while interest and rental incomes are proportional to capital and land. Thus this model generates a degree of wealth inequality which is higher than that of wage and income inequality, as suggested by the data. After receiving their income net of taxes, individuals make consumption 
and capital bequest decisions by maximizing (3) subject to (4). We can derive the indirect utility function as

$$
v_{t}^{i}=\log I_{t}^{i}+\xi
$$

where $\xi=(1-\partial) \log (1-\partial)+\partial \log \partial$.

\subsection{Bequest taxation}

Bequest taxation is set through a political choice under majority voting with full suffrage. Each individual casts a vote at each period on the contemporaneous level of the tax, $\tau_{t}$, such that $0<\tau_{t}<1$, to be imposed on the bequest he receives. Since the bequest distribution varies over time, as we will show the level of the tax chosen by the median voter will also vary. While capital and land bequests are subject to the same tax rate, we assume that capital is harder to tax than land, so that a fraction $\theta$ of capital avoids taxation, while land is fully subject to it. We interpret $\theta$ as a parameter, rather than a choice variable, since it is meant to capture structural characteristics of a tax system which only radical reforms, rather than routine fiscal policy decisions, could affect. Bequest taxes are subject to proportional collection costs $\tau_{t}^{2}$. Net tax revenues are equally redistributed in proportion to total bequests. There is no other form of taxation and government expenditures. In particular, to impose a wage income tax would not make sense from a redistribution point of view since the wage is identical for all individuals. Government revenues in intensive form at each $t$ are given by $\tau_{t}(1-\theta) k_{t}+\tau_{t} e-\tau_{t}^{2}\left(k_{t}+e\right)$.

Setting a government balanced budget, all revenues are redistributed. The resulting expression for individual income, assuming no depreciation, is given by

$$
I_{t}^{i}=\omega_{t}+\left[1+r_{t}-\tau_{t}(1-\theta)\right] k_{t}^{i}+\left(1+\rho_{t}-\tau_{t}\right) e^{i}+\left(\tau_{t}-\tau_{t}^{2}\right)\left(k_{t}+e\right)-\tau_{t} \theta k_{t}
$$

where $\omega_{t}$ is the wage rate, $r_{t}$ is the interest rate on capital and $\rho_{t}$ is the rental rate on land. To be noticed is that, as long as some manufacturing good is consumed, the price of the manufacturing good in terms of the agricultural good is 1 , so that we can simply sum up all income components in (6). Moreover, as the analysis below will clarify, we can also assume that the price of land in terms of capital is 1 , even though strictly speaking the price of land is not defined in a model where land never goes to market. Therefore, we can simply sum up the capital and land holdings which appear in (6). 
The way the tax is levied is crucial for future tractability of the model: here we assume that the tax is paid out of the bequest received, without affecting its ability to be used in production. Consequently, individuals receive interest and rental income over the full amount received as a bequest, and pay the tax out of the amount received and invested. Alternatively, one could have assumed the tax to be imposed on the entire amount of the gross income generated by the investment, thus affecting the wage rate in general equilibrium. Intuitively, a tax imposed on gross income would carry implications similar to the case under consideration.

\section{Analysis of the model}

\subsection{Factor prices}

Under perfect competition in the labor and capital markets, profit maximization yields the following factor prices:

$$
\begin{gathered}
\rho_{t}=\alpha\left(\frac{N_{t}^{A}}{L}\right)^{1-\alpha} \\
\omega_{t}^{A}=(1-\alpha)\left(\frac{L}{N_{t}^{A}}\right)^{\alpha} \\
r_{t}=\alpha\left(\frac{N_{t}^{M}}{K_{t}}\right)^{1-\alpha} \\
\omega_{t}^{M}=(1-\alpha)\left(\frac{K_{t}}{N_{t}^{M}}\right)^{\alpha}
\end{gathered}
$$

where $\omega_{t}^{A}$ and $\omega_{t}^{M}$ are the wage rate in agriculture and manufacturing, respectively. Perfect labor mobility implies that $\omega_{t}^{A}=\omega_{t}^{M}=\omega_{t}$. Equating (8) and (10), we obtain the following expression for $N_{t}^{M}$ :

$$
N_{t}^{M}=\frac{K_{t}}{L} N_{t}^{A}
$$

which shows that the number of workers in manufacturing is an increasing function of the level of the capital stock.

An implication of (11) is that $\rho_{t}=r_{t}$. Therefore, even if the price of land is not defined in the absence of a land market, we can define its implicit price in terms of the present discounted value of the rents accruing to it. It follows that the implicit price of each unit of land will always be equal to the price of capital. 


\subsection{Utility maximization}

The solution to the individual optimization problem is given by the following consumption and capital bequest functions:

$$
\begin{gathered}
c_{t}^{i}=(1-\partial) I_{t}^{i} \\
k_{t+1}^{i}=\partial I_{t}^{i}
\end{gathered}
$$

with total individual bequest being given by $b_{t+1}^{i}=k_{t+1}^{i}+e^{i}$.

Maximizing the resulting indirect utility function (5) with respect to level of the tax, we obtain the following preferred tax level for each individual:

$$
\tau_{t}^{i}=\frac{1}{2}\left[1-\frac{(1-\theta) k_{t}^{i}+\theta k+e^{i}}{k_{t}+e}\right]
$$

Since the second order condition is satisfied so that indirect utility is single-peaked with respect to the tax rate, we can apply the median voter theorem and assert that under majority voting and our assumptions on the distribution of bequests the median voter will set a positive level of the tax $\tau_{t}^{m}$ according to (14), which is most clearly illustrated by

$$
\tau_{t}^{m}=\frac{1}{2}\left[1-\frac{k_{t}^{m}+e^{m}}{k_{t}+e}-\frac{\theta\left(k_{t}-k_{t}^{m}\right)}{k_{t}+e}\right]
$$

To be noticed is that under an alternative tax scheme with the tax imposed on gross income, the problem would not deliver a closed form solution, and possibly not even single-peaked preferences, due to the fact that factor prices would become a function of the tax itself, with the wage rate decreasing and the interest rate increasing with the tax.

\subsection{Market clearing}

To close the model, we now derive the market-clearing condition for the capital market, which aggregating over individual incomes can be written as

$$
K_{t+1}=(1-\delta)\left[Y_{t}+\left(1-\tau_{t}^{m 2}\right)\left(K_{t}+L\right)\right]
$$

where $Y_{t}=Y_{t}^{A}+Y_{t}^{M} \cdot{ }^{10}$ Market clearing in the labor market obtains for

\footnotetext{
${ }^{10}$ The unit price assumption, together with our preferences, implies that some manufacturing goods must be consumed, otherwise the price of the manufacturing good would have to be higher than the price of the agricultural good. In other words, $K_{t+1}<Y_{t}^{M}$ and the saving rate $(1-\delta)$ is bounded above by $\frac{Y_{t}^{M}}{Y_{t}}$.
} 


$$
N_{t}^{A}+N_{t}^{M}=N_{t}
$$

The agricultural and manufacturing goods markets must also be cleared at each $t$, implying

$$
\begin{gathered}
Y_{t}^{A}=c_{t}^{A} N \\
Y_{t}^{M}=c_{t}^{M} N+K_{t+1}
\end{gathered}
$$

From (11) and (17) we can derive the following expression for total output at each $t$ :

$$
Y_{t}=\left\{\left[\psi\left(K_{t}\right)\right]^{1-\alpha} K_{t}^{\alpha}+\left[1-\psi\left(K_{t}\right)\right]^{1-\alpha} L^{\alpha}\right\} N^{1-\alpha}
$$

where $\psi\left(K_{t}\right) \equiv \frac{K_{t}}{K_{t}+L}$.

\subsection{Dynamic political-economic equilibrium}

Definition 1 A perfect-foresight political-economic equilibrium is a sequence

$$
\left\{c_{t}^{A}, c_{t}^{M}, K_{t}, Y_{t}^{A}, Y_{t}^{M}, N_{t}^{A}, N_{t}^{M}, \tau_{t}^{m}\right\}_{t=0}^{\infty}
$$

such that at each $t$ utility and profits are maximized, all markets clear, and the tax rate is optimally set by the median voter, starting from a given initial value of $K_{0}>0$.

The equilibrium path solves simultaneously equations (7)-(10), (12), (13), and (15)-(19).. The evolution of individual capital bequests is given by

$$
k_{t+1}^{i}=\partial\left[\omega_{t}+\left(1+r_{t}-\tau_{t}^{m}(1-\theta)\right) k_{t}^{i}+\left(1+\rho_{t}-\tau_{t}^{m}\right) e^{i}+\left(\tau_{t}^{m}-\tau_{t}^{m 2}\right)\left(k_{t}+e\right)-\tau_{t}^{m} \theta k_{t}\right]
$$

while the evolution of the average capital-bequest level can be tracked by

$$
k_{t+1}=\partial\left[\omega_{t}+\left(1+r_{t}-\tau_{t}^{m}(1-\theta)\right) k_{t}+\left(1+\rho_{t}-\tau_{t}^{m}\right) e+\left(\tau_{t}^{m}-\tau_{t}^{m 2}\right)\left(k_{t}+e\right)-\tau_{t}^{m} \theta k_{t}\right]
$$

which can be restated as

$$
k_{t+1}=\partial\left[y_{t}+\left(1-\tau_{t}^{m 2}\right) b_{t}\right]
$$

Along the equilibrium path, workers migrate to the manufacturing sector as the capital stock grows, while the agricultural sector shrinks. Therefore, the agriculture share of output varies inversely with the level of development. At the same time, the size of the capital stock increases 
while the quantity of land is invariant, so that wealth and bequest composition also evolves. In the long run, the dynamical system evolves towards a steady state which is associated with constant values $K, B, Y^{A}, Y^{M}, N^{A}, N^{M}$, and $\tau^{m}$. The steady state average capital $k$ solves the following expression:

$$
k=\partial\left[e^{\alpha} n^{A 1-\alpha}+k^{\alpha} n^{M 1-\alpha}+\left(1-\tau^{m 2}\right)(k+e)\right]
$$

where $n^{A}$ and $n^{M}$ are the steady-state fractions of labor in agriculture and manufacturing, respectively. Steady-state total average bequests are given by $b=k+e$. Because of the collection costs captured by $\tau^{m 2}$, the higher the tax, the lower the associated $k$. Moreover, the higher $\theta$, the lower the tax and the higher is steady-state $k$. By (11), the tax system also affects labor mobility and structural reallocation from agriculture toward manufacturing.

The evolution of individual capital bequests leads to a steady state capital bequest given by

$$
k^{i}=\frac{\partial}{1-\partial\left[1+r-\tau^{m}(1-\theta)\right]}\left[\omega_{t}+\left(1+\rho_{t}-\tau^{m}\right) e^{i}+\left(\tau^{m}-\tau^{m 2}\right)(k+e)-\tau^{m} \theta k\right]
$$

where capital inequality simply depends on initial land inequality, even though the relative weight of land inequality is diluted at steady state by the growth of the capital component of total bequests. Similarly, $b^{i}=k^{i}+e^{i}$. Thus, even though initial land inequality prevents convergence of the capital and bequest distributions to full equality, the dynamics of the system predict a gradual reduction of capital and bequest inequality. Nevertheless, $k_{t}^{m}<k_{t}$ at each $t$, confirming the property assumed for the initial distribution of capital and also implying that wealth inequality always remains higher than wage and income inequality. Moreover, while convergence is accelerated by the redistribution scheme, accumulation is slowed down by the costs of collection.

\subsection{The comparative statics of bequest taxation}

The expression for the tax rate derived in (15) has an intuitive interpretation. The second term in square brackets, $\frac{k_{t}^{m}+e^{m}}{k_{t}+e}=\frac{b_{t}^{m}}{b_{t}}$, captures the standard Meltzer and Richard (1981) mechanism: the preferred tax is higher, the smaller is the median bequest if compared with the average bequest, where both components of the bequest are treated symmetrically. When tax avoidance is absent and $\theta=0,(15)$ reduces to $\tau_{t}^{m}=\frac{1}{2}\left(1-\frac{b_{t}^{m}}{b_{t}}\right)$, so that the gap between the median and the mean bequest is the only relevant consideration: the tax rate is strictly positive as long as the median bequest is lower than the mean, otherwise the median voter would set the tax at 0 . Thus, in a full compliance, symmetric tax system, bequest inequality is the only determinant of the tax rate. 
However, for $\theta>0$, the third term in square brackets increases with $\theta$, and with the gap between the median and the mean of that bequest component - capital - which is associated with tax avoidance. It follows that the tax rate chosen by the median voter is decreasing in the avoidance rate for capital exhibited by the tax system, and that the negative impact of $\theta$ on $\tau_{t}^{m}$ intensifies with capital inequality as a proportion of total wealth. Capital inequality therefore induces a reduction of the tax rate below its full compliance, maximum level. The third term can be interpreted as a measure of the asymmetry in the tax system due to the dysfunctions of capital tax collection. In particular, when $\theta=1$, i.e., capital completely avoids taxation, the level of the tax is at its minimum, since the asymmetry induced by tax avoidance is maximized. Expression (15) reduces to $\frac{1}{2}\left(1-\frac{k_{t}+e^{m}}{k_{t}+e}\right)$, which implies that land inequality is the sole determinant of the tax rate in each period. ${ }^{11}$ These results can be summarized as follows.

Proposition 1 At each $t$ the level of the tax rate $\tau_{t}^{m}$ increases with bequest inequality $\frac{b_{t}^{m}}{b_{t}}$ and decreases with the tax avoidance rate for capital $\theta$.

\subsection{The evolution of bequest taxation}

Our original focus is on the evolution of taxation as determined by

$$
\frac{\tau_{t+1}^{m}}{\tau_{t}^{m}}=\frac{(1-\theta)\left(k_{t+1}-k_{t+1}^{m}\right)+\left(e-e^{m}\right)}{(1-\theta)\left(k_{t}-k_{t}^{m}\right)+\left(e-e^{m}\right)} \frac{k_{t}+e}{k_{t+1}+e}
$$

which is smaller than 1 , thus indicating a decline toward a steady state value.

By inspection of (26), the decline of the tax rate chosen by the median voter is caused by two forces: the evolution of wealth inequality and capital accumulation. The former is captured by the first term, which is smaller than 1 because capital inequality declines and the gap between mean and median capital is reduced over time. To be noticed is that the larger is land inequality, i.e., the difference $e-e^{m}$, the slower the strength of this first factor, since land inequality is time invariant. $^{12}$

The latter force is captured by the second term, which is also smaller than 1 because average capital grows over time. This second force magnifies the first one by increasing the capital component relative to land.

\footnotetext{
${ }^{11}$ For the sake of comparison, the tax rate in this case is also below the level that would apply to a scheme according to which taxes and transfers are solely determined on the basis of land holdings.

${ }^{12}$ As already discussed in Section 3 and in footnote 9, our assumption is consistent with the available evidence.
} 
However, there is also a third factor affecting the evolution of taxation in the opposite direction: the larger is tax avoidance for the capital component of wealth, the weaker the impact of capital equalization and the slower the decline of the tax. Therefore, tax avoidance delays the adjustment of the tax system to the changing structure of the economy. For tax avoidance to have any impact, land must be unequally distributed, which is always the case under our assumptions. ${ }^{13}$

In particular, in a full compliance system with $\theta=0,(26)$ reduces to $\frac{b_{t+1}-b_{t+1}^{m}}{b_{t}-b_{t}^{m}} \frac{b_{t}}{b_{t+1}}$, where the first term is smaller than for a positive $\theta$, thus implying a faster decline of the tax. In other words, under full compliance the equalization force exerts its maximum impact on tax reduction. On the other hand, if capital fully avoids taxation and $\theta=1,(26)$ simplifies to $\frac{b_{t}}{b_{t+1}}$, so that the decline of the tax is purely associated with capital accumulation. Finally, it should be noticed that the impact of $\theta$ on the process is gradually reduced as capital bequests tend to equalization. In other words, in more capital-equal economies the asymmetry between capital and land matters less, while it matters more when capital inequality is still relatively large. Over a cross section, this implies that differences in tax avoidance behavior tend to be more important in more unequal countries.

Our main results are summarized in the following proposition.

Proposition 2 Over time the sequence of tax rates $\left\{\tau_{t}^{m}\right\}_{t=0}^{\infty}$ decreases with the reduction of bequest inequality and with capital accumulation, at a rate which is decreasing in land inequality and in the tax avoidance rate for capital $\theta$. The impact of $\theta$ is increasing in capital inequality.

For $0<\theta<1$, in the long run the level of the tax rate converges to a positive level given by

$$
\tau^{m}=\frac{1}{2}\left[1-\frac{k^{m}+e^{m}}{k+e}-\frac{\theta\left(k-k^{m}\right)}{k+e}\right]
$$

which is bounded above 0 by the presence of land, preventing the convergence to 1 of the second term and to 0 for the third. The steady state level of the tax is increasing in inequality and decreasing in tax avoidance. In particular, in a full compliance system the steady state tax is given by $\frac{1}{2}\left(1-\frac{k^{m}+e^{m}}{k+e}\right)$, which is higher than its full avoidance analog, $\frac{1}{2}\left(1-\frac{k+e^{m}}{k+e}\right)$.

The implications of the decline of taxation for the evolution of average and individual capital and bequest are the following. By (24), $k$ is affected by the tax, but in turn the tax will have reached its minimum level by the time a steady state is reached. Therefore, in the limit, the impact of the tax on total capital and bequests will be negligible. In the long run the impact of taxation

\footnotetext{
${ }^{13}$ The impact of $\theta$ would only vanish if land inequality were absent, with $e=e^{m}$ - which never occurs here - and does not depend on the fraction of land over total bequests.
} 
on individual capital will also become negligible, with the wage rate and initial land holdings representing its main determinants. On the other hand, the relative weight of initial land holdings will also be reduced by the process of development, while at the same time the unit rent will decline. Therefore, the common wage component will constitute the most important determinant of individual capital holdings in the long run. It is the growing role of labor income in wealth determination that drives the process of equalization in this model.

To sum up, the evolution of taxation in this model is shaped by wealth equalization, sectoral reallocation, and by the avoidance rate exhibited by the tax system, and in particular by the capital component of wealth. In particular, larger compliance implies a larger level of taxation but also its faster decline, while avoidance makes the tax system slow to adjust to the changing structure of the economy. The policy implications are that, as the distribution of bequests equalizes over time, the political justification for bequest taxation should also decline, and that at the same time high avoidance keeps taxation at a low but persistent level throughout the process.

Our results so far replicate the observed reduction of bequest taxation, starting from the 1930s. Moreover, our first suggested explanation for this trend, i.e., a reduction of wealth inequality, is matched by the data reported in Section 3. Section 3 also documents the process of capital accumulation and industrialization during the relevant time period, thus corroborating our second explanation of tax reduction. Moreover, the evidence shows that the initial degree of land inequality was higher in Western Europe than in the US, pointing to this as a possible cause of the observed differences in the speed of decline of tax revenues, which has been lower in Europe.

Finally, the available data on tax compliance are consistent with the role that our model assigns to this parameter, with low-compliance Western European countries exhibiting lower, but more stable bequest tax rates than the high-compliance US. As predicted by Proposition 2, the impact of tax avoidance may also have been magnified by capital inequality, which appears to have been higher in the United States. Different degrees of avoidance, combined with extreme degrees of capital inequality, could also be the explanation of the radical differences between the systems of taxation in developed and underdeveloped countries, with wealth and bequest taxes playing a minor role in the latter. 


\section{Extensions}

\subsection{Franchise requirements and the initial rise of bequest taxation}

In this first extension of the basic model we allow for franchise requirements to be imposed on the voting mechanism. While there is a well-established literature which has dealt with the historical reasons for the observed expansion of the franchise, ${ }^{14}$ the scope of the present paper is just to evaluate its effect on the issue of interest, by considering an exogenous franchise requirement for participation in the voting process. ${ }^{15}$ The requirement is expressed in terms of a minimum bequest level. This wealth threshold is not to be strictly interpreted as a rule specified by the voting mechanism and thus potentially set and adjusted by the elite in power, but as a parameter meant to capture the broader fact that an exogenously-determined socioeconomic status is necessary to permit political activism. Under this assumption, we can apply to the model previously developed the main intuition advanced by Meltzer and Richard (1981), according to which extensions of the franchise should be accompanied by an increase in tax revenues, and study how the interaction between franchise extension and the evolution of wealth inequality, taking into account sectoral reallocation, affects tax policy.

Let the franchise requirement be set at a bequest level $\widetilde{b} \geq b_{0}$. In other words, initially the median voter is richer than the mean individual. This implies $\tau_{0}^{m}=0$. The accumulation process provokes growth of the average bequest. Nevertheless, taxation will not be introduced until the time $t^{\prime}$ at which a sufficient number of people have crossed $\widetilde{b}$, so that the median voter is poorer than the mean: this implies $\tau_{t^{\prime}}^{m}>0$. At this early stage, when wealth is mostly constituted by land, the relative avoidance rate of the tax system, and in particular capital tax avoidance, represent marginal considerations. After $t^{\prime}$ the tax rate keeps increasing until full enfranchisement is reached, say, at time $t^{\prime \prime}$, with $\tau_{t^{\prime \prime}}^{m}$ representing the highest tax rate in this economy's history. From then on, the tax rate reacts to the continuous decline of wealth inequality and to industrialization, and decreases over time at a rate which is inversely related to the avoidance rate, according to the previous analysis, which can in fact be reinterpreted as the description of an economy which starts at time $t "$ with full enfranchisement.

In the extended framework, the tax is 0 until $t^{\prime}$, it then increases until $t$ ", and eventually

\footnotetext{
${ }^{14}$ See Justman and Gradstein (1999), Acemoglu and Robinson (2000), Bertocchi and Spagat (2001), Lizzeri and Persico (2004), Llavador and Oxoby (2005), Jack and Lagunoff (2006), and Cervellati et al. (2005).

${ }^{15}$ Saint-Paul and Verdier (1993), Bertocchi and Spagat (2004) and Bertocchi (2006) also introduce an exogenous franchise requirement.
} 
keeps decreasing afterwards. This pattern replicates the humped-shaped long-term evolution of the bequest tax for those countries that are now modern industrial democracies, where the tax is introduced and progressively expanded in the 19th century when wealth inequality is still very high, reaches a peak in the 1930s and 1940s, and is subsequently reduced after World War II. Indeed, as discussed in Section 3, most modern democracies actually reached full male enfranchisement around 1920. It is reasonable to expect that the impact of the new political climate, more oriented toward taxation of large fortunes, was felt in the actual policy decisions and in the bequest tax revenues data in the next few decades.

Moreover, the same framework can also explain why different countries historically developed different modern systems of taxation. Sokoloff and Zolt (2005) analyze the comparative evolution of tax systems in the Americas over the past two centuries and document that in the 19th century Latin America designed a highly regressive system, while North America embraced a progressive one. This pattern is associated to the much higher degree of economic and political inequality in Latin America, which allowed the local elites to develop a tax system that preserved inequality. In our framework, a relatively high franchise requirement, and/or extreme poverty on the lower side of wealth distribution, could indeed prevent democratization as well as the implementation of tax policies for a protracted period of time.

Finally, this version of the model can also suggest another reason - beside high avoidance - for the deep contrasts still existing today between the tax systems of modern industrial democracies and those of underdeveloped countries, with the latter showing much less reliance on bequest and wealth taxation, and progressive taxation in general. These differences can be explained by the low degree of democracy prevailing in most underdeveloped countries acting in combination with extreme inequality.

\subsection{Income taxation and the size of government}

In this subsection we add income taxation in the form of wage taxes. The goal of this exercise is to introduce a preliminary analysis of a more complete system of taxation, and at the same time to offer an explanation of the expansion of the size of government, which has been documented for the post-war period despite the decline of bequest taxation. Once again, we exploit the asymmetry between the agriculture and manufacturing sectors, by assuming that manufacturing wages are easier to tax than agricultural wages. Given the different ways production is organized in the two sectors, with larger and more urbanized production units in manufacturing, this assumption is 
easily justified. To simplify the analysis, we in fact assume that a wage tax is exclusively imposed on manufacturing wages. We further assume that the tax rate on manufacturing wages is set at an exogenous constant level, $\tau^{w}$, and that revenues from wage taxes are earmarked to finance in each period government expenditures $g_{t}$, while revenues from bequest taxes are set and distributed as previously assumed. Within this framework, industrialization will determine an expansion of the tax base for wage taxation, thus allowing an expansion of government expenditures at a rate which is linked to the rate of growth of employment in manufacturing, which as a country industrializes is higher than the rate of growth of total income before a steady state is reached.

Thus, combining the two forms of taxation, even if redistributive bequest taxation declines over time, the size of government can actually increase because of the government expenditures component. Since in 1999 the latter represented the bulk of total government outlays $(69.5 \%$ and $62.2 \%$ in the US and the EU, respectively) ${ }^{16}$, our theory of bequest taxation can be reconciled with the overall evidence on the evolution of government budgets.

\subsection{Land vs. housing}

While in our model wealth reallocation from land to capital is one of the driving forces behind the long-term evolution of bequest taxation, another crucial distinction, between physical capital and housing, becomes even more important in current policy applications. Land and housing share the common feature of being relatively easier to tax than capital. However, unlike land, the distribution of real estate is increasingly characterized by the fact that the middle class holds an overwhelming proportion of wealth in it, in the form of principal residence. This is due to the fact that, on the one hand, poor people are liquidity constrained and cannot afford to buy a house, while on the other residential investment only needs to absorb a fraction of total wealth for the rich. Decomposing inequality by wealth components in order to incorporate this assumption would make the model more complicated. However, the dynamics would be simplified by the fact that one would not need to embed a reallocation mechanism from capital to real estate. While we leave this extension for future research, it is clear that a middle class with a higher stake in an easy-to-tax asset would only push toward an even lower level of the tax rate, confirming our original intuition regarding the role of land.

\footnotetext{
${ }^{16}$ The source are OECD data as elaborated by Alesina et al. (2001).
} 


\section{Conclusion}

Our goal was to explain the comparative evolution of bequest taxation in a historical perspective. To this end, we have developed a dynamic, two-sector version of the Meltzer and Richard (1981) median voter model where taxes are imposed on bequests. Wealth is more unequally distributed than income, because it is transmitted through unequal bequests. However, since the model allows the distribution of wealth to evolve over time, bequest taxation as set by a median voter will also evolve over time. The model also captures the impact of industrialization on the bequest tax base, through an asymmetry between land and capital taxation. The convergence of wealth distribution and industrialization imply a gradual decline of bequest taxation, but the asymmetry in the tax avoidance rate between land and capital also matters, with a high rate of avoidance for capital negatively affecting both the level and the speed of adjustment of the tax to the changing economic structure. The results match the relevant stylized facts regarding bequest tax revenues, as well as the dynamics of wealth inequality and structural reallocation from agriculture to manufacturing.

Adding initial franchise requirements to this framework allows to reproduce the humped-shaped long term evolution of the bequest tax starting from the 19th century for those countries that are now modern industrial democracies. Moreover, our conclusions can be reconciled with the available evidence on the growing size of government, and can be extended to a framework where real estate, rather than land, is the relevant alternative to capital.

The implications of these results for policy is that, if the pattern exposed by the recent long term investigations of wealth inequality in rich democracies is not to be reversed in the future, the fate of the death tax is probably going to be death. On the other hand, for developing countries with high rates of tax avoidance, extreme wealth inequality and/or undemocratic political systems, the current burden of bequest and wealth taxes appears to be too low, making the case for an expansion of this policy tool in the future.

While the present investigation has been mostly focused on bequest taxation, a goal for future research is to understand those factors that have shaped the evolution of the broader institutions of taxation across different countries. While so far we have highlighted the role of wealth inequality and structural reallocation, other factors such as the share of wages over profits, the impact of globalization, as well as ethnic conflict and family structure, can also be evaluated as potentially relevant. This research would extend our understanding of how institutions interact with the processes of economic growth and development. 


\section{References}

Aaron, H.J., and Munnell, A.H., 1992, Reassessing the Role for Wealth Transfer Taxes, National Tax Journal 45, 119-43.

Acemoglu, D. and Robinson, J., 2000, Why Did the West Extend the Franchise? Democracy, Inequality and Growth in Historical Perspective, Quarterly Journal of Economics 115, 116799.

Aizenman, J. and Jinjarak, Y., 2006, Globalization and Developing Countries: A Shrinking Tax Base?, NBER Working Paper No. 11933.

Alesina, A., Glaeser, E. and Sacerdote, B., 2001, Why Doesn't the United States Have a EuropeanStyle Welfare State?, Brookings Papers on Economic Activity 2, 187-278.

Alesina, A. and Rodrik, D., 1994, Distributive Politics and Economic Growth, Quarterly Journal of Economics 109, 465-90.

Atkinson, A., Gordon, J. and Harrison, A., 1989, Trends in the Shares of Top Wealth-holders in Britain, 1922-1981, Oxford Bulletin of Economics and Statistics 51, 316-32.

Atkinson, A. and Piketty, T., 2007, Top Incomes over the Twentieth Century, Oxford University Press, Oxford.

Auerbach, A.J., 2006, Why Have Corporate Tax Revenues Declined? Another Look, NBER Working Paper No. 12463.

Aura, S., 2004, Estate and Capital Gains Taxation: Efficiency and Political Economy Considerations, CESifo Working Paper No. 1198.

Azzimonti, M., de Francisco E. and Krusell, P., 2005, Median-voter Equilibria in the Neoclassical Growth Model under Aggregation, mimeo.

Banks, A., 2001, Cross-National Time Series, 1815-1999, Center for Comparative Political Research, State University of New York, Binghamton.

Benabou, R., 2000, Unequal Societies: Income Distribution and the Social Contract, American Economic Review 90, 96-129. 
Bendix, R., 1978, Kings or People: Power and the Mandate to Rule, University of California Press, Berkeley.

Benhabib, J., and Bisin, A., 2006, The Distribution of Wealth and Redistributive Policies, mimeo.

Bertocchi, G., 2006, The Law of Primogeniture and the Transition from Landed Aristocracy to Industrial Democracy, Journal of Economic Growth 11, 41-68.

Bertocchi, G. and Spagat, M., 2001, The Politics of Co-optation, Journal of Comparative Economics 29, 591-607.

Bertocchi, G. and Spagat, M., 2004, The Evolution of Modern Educational Systems: Technical vs. General Education, Distributional Conflict, and Growth, Journal of Development Economics $73,559-82$.

Blumkin, T. and Sadka, E., 2003, Estate Taxation with Intended and Accidental Bequests, Journal of Public Economics 88, 1-21.

Burgess, R. and Stern, N., 1993, Taxation and Development, Journal of Economic Literature 31, $762-830$.

Caucutt, E. M., Cooley, T. F. and Guner, N., 2006, The Farm, the City, and the Emergence of Social Security, mimeo.

Cervellati, M., Fortunato, P. and Sunde, U., 2005, Hobbes to Rousseau: Inequality, Institutions, and Development, IZA Discussion Paper No. 1450.

Chamley, C., 1986, Optimal Taxation of Capital Income in General Equilibrium with Infinite Lives, Econometrica 54, 607-22.

Cremer, H. and Pestieau, P., 2005, Wealth Transfer Taxation: A Survey, in Gerard-Varet, L.A. , Kolm, S.C. and Mercier Ythier, J. (eds.), Handbook on the Economics of Giving, Reciprocity and Altruism, North-Holland.

Cukierman, A., Edwards, S. and Tabellini, G., 1992, Seigniorage and Political Instability, American Economic Review 82, 537-55.

Das, S. and Ghate, C., 2004, Endogenous Distribution, Politics, and the Growth-Equity Tradeoff, Contributions to Macroeconomics, Berkeley Electronic Press 4, 1-30. 
Davies, J.B., Sandstrom, S., Shorrocks, A. and Wolff, E.N., 2006, The World Distribution of Household Wealth, mimeo.

De Nardi, M., 2004, Wealth Inequality and Intergenerational Links, Review of Economic Studies $71,743-68$.

Diaz-Gimenez, J., Quadrini, V. and Rios-Rull, J.-V., 1997, Dimensions of Inequality: Facts on the U.S. Distributions of Earnings, Income and Wealth, Federal Reserve Bank of Minneapolis Quarterly Review 21, 3-21.

Duff, D.G., 2005, The Abolition of Wealth Transfer Taxes: Lessons from Canada, Australia, and New Zealand, University of Toronto Legal Studies Research Paper No. 05-08.

Eaton, J., 1987, A Dynamic Specific-Factors Model of International Trade, Review of Economic Studies 54, 325-338.

Engerman, S. L., and Sokoloff, K. L. 1997, Factor Endowments, Institutions and Differential Paths of Growth Among New World Economies: A View from Economic Historians from the United States, in Haber, S. (ed.), How Latin America Fell Behind, Stanford University Press, Stanford.

Farhi, E. and Werning, I., 2006, Progressive Estate Taxation, mimeo.

Flora, P., 1983, State, Economy, and Society in Western Europe 1815-1975: A Data Handbook -Vol. I: The Growth of Mass Democracies and Welfare States, St. James Press, Chicago.

Frankema, E., 2006, The Colonial Origins of Inequality: Exploring the Causes and Consequences of Land Distribution, Groningen Growth and Development Centre Research Memorandum GD-8.

Galor, O., Moav, O. and Vollrath, D., 2006, Inequality in Land Ownership, the Emergence of Human Capital Promoting Institutions and the Great Divergence, mimeo.

Galor, O. and Zeira, J., 1993, Income Distribution and Macroeconomics, Review of Economic Studies 60, 35-52.

Gale, W.G. and Slemrod, J., 2001, Rethinking the Estate and Gift Tax: Overview, in Gale, W.G., Hines, J.R.Jr. and Slemrod, J. (eds.), Rethinking Estate and Gift Taxation, Brookings Institution, Washington. 
Gollin, D., Parente, S. and Rogerson, R., 2002, The Role of Agriculture in Development, American Economic Review 92, 160-64.

Goody, J., Thirsk, J. and Thompson, E.P. (eds.), 1976, Family and Inheritance: Rural Society in Western Europe 1200-1800, Cambridge University Press, Cambridge.

Jack, W. and Lagunoff, R., 2006, Dynamic Enfranchisement, Journal of Public Economics 90, $551-72$.

Justman, M. and Gradstein, M., 1999, The Industrial Revolution, Political Transition, and the Subsequent Decline in Inequality in 19-th Century Britain, Explorations in Economic History $36,109-27$.

Harbury, C.D., 1973, Inheritance and the Distribution of Personal Wealth in Britain, Economic Journal 83, 810-33.

Hassler, J., Rodriguez Mora, J.V., Storesletten, K. and Zilibotti, F., 2003, The Survival of the Welfare State, American Economic Review 93, 87-112.

Kapteyn, A. and Panis, C., 2002, The Size and Composition of Wealth Holdings in the United States, Italy, and the Netherlands, RAND DRU-2767-DOL.

Kopczuk, W., 2003, The Trick is to Live: Is the Estate Tax Social Security for the Rich?, Journal of Political Economy 111, 1318-41.

Kotlikoff, L. J. and Summers, L. H., 1981, The Role of Intergenerational Transfers in Aggregate Capital Accumulation, Journal of Political Economy 89, 706-32.

Krusell, P. and Rios-Rull, J.-V., 1999, On the Size of Government: Political Economy in the Neoclassical Growth Model, American Economic Review 89, 1156-81.

Laitner, J., 2001, Secular Changes in Wealth Inequality and Inheritance, Economic Journal 111, 691-721.

Lizzeri, A., and Persico, N., 2004, Why Did the Elites Extend the Suffrage? Democracy and the Scope of Government, with an Application to Britain's 'Age of Reform', Quarterly Journal of Economics 119, 707-65.

Llavador, H. and Oxoby, R.J., 2005, Partisan Competition, Growth and the Franchise, Quarterly Journal of Economics 120, 1155-89. 
Meltzer, A.H. and Richard, S.F., 1981, A Rational Theory of the Size of Government, Journal of Political Economy 89, 914-27.

North, D.C., 1981, Structure and Change in Economic History, Norton, New York.

Persson, T. and Tabellini, G., 1994, Is Inequality Harmful for Growth?, American Economic Review 84, 600-21.

Piketty, T. and Saez, E., 2007, How Progessive is the US Federal Tax System? A Historical and International Perspective, Journal of Economic Perspectives 21, forthcoming.

Saint Paul, G. and Verdier, T., 1993, Education, Democracy and Growth, Journal of Development Economics 42, 399-407.

Sokoloff, K.L. and Zolt, E.M., 2005, Inequality and the Evolution of Institutions of Taxation: Evidence from the Economic History of the Americas, in Edwards, S. (ed.), Growth, Institutions and Crises: Latin America from a Historic Perspective, University of Chicago Press, Chicago.

Wolff, E.N., 1996, International Comparisons of Wealth Inequality, Review of Income and Wealth $42,433-52$.

World Economic Forum, 1996, The Global Competitiveness Report 1996, World Economic Forum, Geneva. 